\title{
Students' Perceptions of Cell Phones and Emotional Behaviour of Undergraduates in Nigerian Universities
}

\author{
Beatrice O. Ajidahun, PhD. \\ Lecturer Department of Guidance and Counselling, Faculty of Education, \\ Adekunle Ajasin University, PMB 001, Akungba Akoko Ondo State, Nigeria \\ Email: wumiajid@yahoo.co.uk
}

\section{Doi:10.5901/jesr.2014.v4n6p183}

\begin{abstract}
The study examined students' perceptions of cell phones and emotional behaviour patterns in Nigerian universities. A total number of 140 students were randomly selected from three universities. The subjects were exposed to Cell Phone Perception Questionnaire (CPQ) consisting of 17 items. Four hypotheses were formulated and tested at 0.05 level of significance. The data were analysed using chi-square statistics. Results showed that emotional reactions and sleep were not significantly related to students' perceptions of cell phone while types of messages received and financial addiction implications were significantly related to students' perceptions of cell phones.
\end{abstract}

Keywords: Cell Phone; Perception; Behaviour; Adolescents.

\section{Introduction}

Communication is a global phenomenon. It is part of life, and there is no one on earth who is not involved in it in one way or the other. In other words, communication is important to individuals and nations to survive. It involves verbal and nonverbal aspects, which include gesture, emotions, words, facial expressions and tone of the voice. According to HunterCrash et al (2006), most communications have aims and take place in a social context that influences how messages are formulated and understood. He went further to say that communication is irreversible and no amount of explanation can erase a bad impression, words said and deeds done are irreversible.

According to Prensky (2005) communication involves speaking, writing, drawing, dancing, playing of music, drama and sport. Due to technological advancement, modern gadgets like the cell-phones are now available as media of communication. These cell phones are very easy and convenient for individuals to take around, and as such they have made communication more convenient and effective.

In Nigeria, since the advent of cell phone for more than a decade now, there have been a lot of improvements in communication although there have also been some problems. According to Amkpa and Okon (2006), mobile communications were licensed to operate in Nigeria during the administration of the former President Olusegun Obasanjo. MTN Nigeria and the then Econet wireless were licensed to operate the same year. Many other networks have since been licensed to operate in Nigeria. Aragbu-Akpor (2004) observed that since the introduction of Global System for Mobile Communication (GSM,) cell phone industries have gained popularity among the Nigerian people especially among the youths.

The cell-phone, which can also be called a mobile phone, mobile cellular telephone or hand phone according to Wikipedia, is an electronic device used for full duplex two-way radio telecommunication over a cellular network of base stations known as cell site. Today, cell phone is more than a phone; it is more like a mobile computer and entertainment unit. The use of cell phone makes interpersonal and interpersonal communication effective. There are lots of benefits derivable from the use of cell phones.

Mobile phones are used for different purposes. For instance, they are very helpful in keeping in touch with family members, especially parents who worry about the whereabouts of their children. They help them to check on their children easily. Businesses are conducted conveniently through the use of cell phones. Having access to a mobile phone in an emergency situation may sometimes help to reduce anxiety. Mobile phone, because of its spread, may sometimes help lift the poor out of poverty. It may improve livelihood of the poorest people in developing countries. It has provided employment and job opportunities to people with little education and few resources. Many of them now sell airtime on the streets and repair handsets. Besides, communication is now enhanced. Anxiety has been reduced over one's loved 
ones. Instructions and messages are now received promptly and immediately. In fact, it has made the world to function as a global village.

Despite the numerous merits of the cell phone, it also has its demerits as well. According to Johnson \& Kristonis (2007) the use of cell phones limits feedback to express to one's peers making life more solitary by narrowing the variety of personalities encountered in daily life. Lots of young people have developed unhealthy emotional attachment because of technological capabilities of the cell phone and its potentials to facilitate socialization. Some may even develop an addiction to the device that excludes anything not viewed or heard through it. The use of mobile phone allows only verbal disembodied relationship at a time when adolescents should be working on developing a sense of their own. It also limits development of the ability to converse in complete thoughts and form complete sentences because the use of texting and spontaneous conversation has limited this. On safety issues, the use of mobile phone can cause hazards for new drivers or people who lack adult experience reaction ability and spatial perception. Cell phone calls and text messages during class can also cause distraction, and it can also be used to cheat during examination (Gilroy, 2003)

In the school setting, cell phones may be used for effective communication between lecturers and students. Komanyane \& Grand (2005) reported that $90 \%$ of the university students at seven universities in Japan owned cell phones capable of sending and receiving e-mail messages. Sixty five percent of the students in the survey also admitted to receiving or sending at least one e-mail message during class while 30\% owned up to sending or receiving as many as four messages. This shows that students use cell phones for short message communication because the service is cheap, convenient and provides the flexibility of communication from anywhere anytime.

According to Muttla, Komanyane and Grand (2005), cell phone had helped students to manage time, eased communication and helped them to keep touch with friends, lecturers and parents. The result of the study carried out by these authors showed that cell phones were used by students mostly for communication purposes to enhance contacts, leisure schedules and academic work.

According to Levinson (2004), many view cell phones as an essential item, an integral tool necessary for family, work, safety and social networking. He opines that people spend most of their phone time contacting close friends, partners or family members. The perception of cell phone may strongly be affected by factors like age, gender, employment and status. Many students may feel that without cell phone they are out of the loop. The more friends they have the more they may feel dependent on their phones and they may allow call or text messages interfere with their daily schedule.

In modern neurobiological terms, according to Damasio (2007), emotions are complex programme of actions triggered by the presence of certain stimuli, external to the body or from within the body, when such stimuli activate certain neutral systems. Feelings of emotions, on the other hand, are perceptions of the emotional actions. He went on to say that for an individual to survive, the contribution of emotions cannot be overemphasized.

According to Craig (2002), each emotion is a collection of bodily actions and these actions are well differentiated so that the overall perception of the particular action programme of a given emotion yields a distinct pattern. The author is of the view that emotion is wide but finite in humans. It includes the programmes of fear, disgust, sadness joy, anger and surprise as well as a group of simpler programmes such as enthusiasm or discouragement known as background emotions. It also includes a group of very complex emotions such as embarrassment, shame, guilt, contempt compassion and admiration.

The focus and emphasis of this study however is on the students' perception of cell-phone and the emotional behaviour pattern of Nigerian undergraduate students. That is, how the undergraduates perceive the cell phone and the emotional pattern attached to it. According to Sanchez etal and Otero (2009), mobile phone exposure includes mental overload, disturbed sleep, the feeling of never being free, role conflicts and feelings of guilt due to inability to return all calls and messages.

Furthermore, emotional attachment to cell phone and dependency were areas of concern associated with exposure to cell phone. Another area of emotions is addiction to the mobile phone; many undergraduates are sometimes addicted to the use of cell phone. They cannot do without their phones. They sometimes view it irrational being without a phone whether it is forgotten, stolen or lost. Without cell phone, some people may feel like they are out of the loop. Studies carried out by some researchers revealed that $37 \%$ of undergraduates felt they would not be able to live without a cell phone once they had it. Cell phone is seen today as part of daily life and a necessity for everyone. It is seen as the easiest instrument of connection.

According to Takao et al (2009), the key determinant of emotional attachment may be the extent to which a person actually perceives his or her own accessibility as stressful. According to the author, accessibility implies the possibility of being disturbed at all hours, even at night time. Having one's sleep interrupted repeatedly can have direct effects on 
recovery and health. Another area of concern may be addiction to the mobile phone. Overuse of mobile phones has been associated with somatic complaints, anxiety and insomnia lifestyle. This study is based on the theoretical assumption of behavioural counselling. Behaviour counselling involves activities to foster behavioral changes.

According to Kanfer and Goldstein (1991), behavioural counselling is of the view that youths are having problems because of maladaptive learning pattern, and so they will need to learn new life skills. Counselling is based on the premises that human beings are born into the world basically empty headed, with a few reflexes. The values, attitude, preference, emotion responses, thinking patterns, personality styles and problems are the results of learnt behaviour. This implies that addiction to cell phone and emotional attachment to it are all learnt by adolescents. The maladaptive attitude of the adolescents to the use of cell phones and their perception of cell phone can be corrected through the use of proper counselling.

According to O'Leary Wilson (1987), the core characteristics of behavior therapy are the following;

- Most abnormal behavior is acquired and maintained according to the same principle.

- People are best described by what they think, feel, and do in specific life situation.

- Assessment is continuous and focuses on the current determinants.

- Treatment goals and methods are mutually contracted with the client.

Weisz et al (2004) found behavior therapy effective in carefully monitoring the behavior of adolescents so that abuse and harm can be avoided. This is possible because the counsellor

has a more forceful role in behavioural counselling.

\section{Purpose of the Study}

The purpose of this study is to investigate whether there are associations between emotional aspects of mobile phone use and behaviour pattern of undergraduate students. These behaviour patterns include stress, sleep disorders, addiction to phone and symptoms of depression.

\section{Research Hypotheses}

For the purpose of this study, four hypotheses were formulated and tested at 0.05 of significance.

1. There is no significant relationship between students' perception of cell phone and emotional reactions.

2. There is no significant relationship between students' perception of cell phone and sleep disorder.

3. There is no significant relationship between students' perception of cell phone and the type of message received.

4. There is no significant relationship between students' perception of cell phone and financial addiction implications.

\section{Population and Sampling Procedure}

The population consists of all full-time undergraduate students in three Universities in South West, Nigeria. The universities are Ekiti State University Ado-Ekiti (EKSU), Federal University of Technology (FUTA) Akure and Adekunle Ajasin University (AAUA) Akungba Akoko. A total number of 140 students were randomly sampled. The students sampled were from different Faculties and Departments.

\section{Validity of the Instrument}

Research instrument was given face and content validity by the researcher.

\section{Reliability of the Instrument}

The reliability of the instrument was established using the test re-test method.

The instrument was administered twice within two weeks interval on 20 students of College of Education, Ikere,

Ekiti State. The test re-test reliability co-efficient was found to be 0.69 and the instrument was considered adequate to elicit necessary information from the subjects. 


\section{Research Instrument}

The data for the study were generated through "Cell-Phone Perception Questionnaire" (CPPQ). The questionnaire, which has two sections namely: section A and B, contained 17 items. Section A requires information about students' bio-data, while Section B consists of items which are intended to find out the relationship between students' perception of cell phone and their emotional behavior pattern. The response format is Strongly Agree, Agree, Strongly Disagree and Disagree. The response scale is as follows: Strongly Agree $=(1)$ Agreed $=(2)$ Strongly Disagree $=3$ and Disagree $=4$.

\section{Data Analysis}

This data were analysed using chi-square. All hypotheses were tested at 0.05 level of significance.

\section{Results}

\subsection{Hypothesis One}

This states that there is no significant relationship between students' perception of cell phone and their emotional reactions.

Table 1: Relationship between Students' Perception of Cell phone and Emotional Reactions.

\begin{tabular}{|c|c|c|c|c|c|}
\hline & & & & Res & ponses \\
\hline $\mathrm{S} / \mathrm{N}$ & \multicolumn{3}{|c|}{ Items } & Agree & Disagree \\
\hline 1. & \multicolumn{3}{|c|}{$\begin{array}{l}\text { If the cell phone of a student is } \\
\text { Misplaced or stolen, he or she sometimes feels miserable, sad and can even cry. }\end{array}$} & 120 & 20 \\
\hline 2. & \multicolumn{3}{|c|}{ Some students steal cell phones because of class consciousness. } & 93 & 47 \\
\hline 3. & \multicolumn{3}{|c|}{ Many students use quality time on their cell phones either for calling browsing or sending text messages. } & 123 & 17 \\
\hline 4. & \multicolumn{3}{|c|}{ Most students see their cell phones as part and parcel of their daily lives. } & 123 & 17 \\
\hline & \multicolumn{3}{|c|}{ Total } & 459 & 101 \\
\hline & & Average Observed Responses & Df & \multicolumn{2}{|c|}{$\mathrm{X} 2 \mathrm{c}$} \\
\hline & Agree & $114.75(70)^{\star}$ & \multirow{2}{*}{1} & \multirow{2}{*}{\multicolumn{2}{|c|}{0.192}} \\
\hline & Disagree & $25.25(70)^{*}$ & & & \\
\hline
\end{tabular}

$\mathrm{X}^{1} \mathrm{t}=3.841 \mathrm{P}<0.05$ (Not significant) *Expected cell frequency

Table 1 shows that the calculated chi-square value which is 0.192 is less than the table value which is 3.841 . Hence the result is not significant. On this ground, the null hypothesis was accepted. It then implies that students' perception of cell of phone and emotional reactions were not related.

\subsection{Hypothesis Two}

This states that there is no significant relationship between students' perception of cell phone and sleep disorder.

Table 2: Relationship between Cell Phone and Sleep Disorder

\begin{tabular}{|c|l|c|c|}
\hline & & \multicolumn{1}{|c|}{ Responses } \\
\hline S/N & \multicolumn{1}{|c|}{ Items } & Agree & Disagree \\
\hline 1. & Have you recently lost much sleep over night calls? & 68 & 72 \\
\hline 2. & $\begin{array}{l}\text { Have you recently been feeling tired and unable to cope with living because of the demands placed } \\
\text { on you by your friends through frequent calls and text messages? }\end{array}$ & 57 & 83 \\
\hline 3. & I am easily awakened by noise, calls and text messages. & 89 & 51 \\
\hline 4. & My sleep is fitful and disturbed by calls. & 64 & 76 \\
\hline 5. & I can sleep during the day but not during the night because of calls from friends. & 35 & 105 \\
\hline & $\quad$ Total & 313 & 387 \\
\hline
\end{tabular}




\begin{tabular}{|c|c|c|c|}
\hline & Average Observed Responses & Df & X2c \\
\hline Agree & $62.6(70)^{\star}$ & \multirow{2}{*}{1} & \multirow{2}{*}{1.564} \\
\hline Disagree & $77.4(70)^{\star}$ & & \\
\hline
\end{tabular}

$\mathrm{X}^{2 \mathrm{t}}=3.841<0.05$ (Not significant) $^{\star}$ Expected cell frequency

Table Two shows that the calculated chi-square value which is 1.564 is less than the table value which is 3.841 . Hence, the result is not significant. On this ground, the null hypothesis was accepted. It implies that students' perception of cell phone and sleep disorder were not related.

\subsection{Hypothesis Three}

This states that there is no significant relationship between students' perception of cell phone and the type of messages received.

Table 3: Relationship Between Cell Phone and Types of Message Received.

\begin{tabular}{|c|c|c|c|c|c|}
\hline & & & & $\operatorname{Re}$ & ponses \\
\hline $\mathrm{S} / \mathrm{N}$ & \multicolumn{3}{|c|}{ Items } & Agree & Disagree \\
\hline 1. & \multicolumn{3}{|c|}{ Many students receive messages on their cell phones that give them emotional disturbance. } & 103 & 37 \\
\hline 2. & \multicolumn{3}{|c|}{ The cell phone is used among undergraduates especially if they are not in the same environment. } & 103 & 37 \\
\hline \multirow[t]{2}{*}{3.} & \multicolumn{3}{|c|}{$\begin{array}{l}\text { Cell-phone messages sometimes strengthen/weaken the opposite sex relationship among } \\
\text { undergraduates. }\end{array}$} & 104 & 36 \\
\hline & \multicolumn{3}{|c|}{ Total } & 310 & 110 \\
\hline & & Average Observed Responses & Df & \multicolumn{2}{|r|}{$\mathrm{X} 2 \mathrm{c}$} \\
\hline & Agree & $103.33(70)^{*}$ & \multirow{2}{*}{1} & \multirow{2}{*}{\multicolumn{2}{|c|}{31.76}} \\
\hline & Disagree & $36.66(70)^{*}$ & & & \\
\hline
\end{tabular}

$X^{2} t=3.841 P<0.05$ (significant) Expected cell frequency

Table Three shows that the calculated chi-square value which is 31.76 is greater than the table value which is 3.841 . Hence, the result is significant. On this ground, the null hypothesis was rejected it implies that students' perception of cell phone and types of message received were related.

\subsection{Hypothesis 4}

This states that there is no significant relationship between students' perception of cell phone and financial addiction implications.

Table 4: Relationship between Cell Phone and Financial Implications

\begin{tabular}{|c|l|c|c|}
\hline & & \multicolumn{2}{|c|}{ Responses } \\
\hline S/N & \multicolumn{1}{|c|}{ Items } & Agree & Disagree \\
\hline 1. & $\begin{array}{l}\text { Some students use sizable amount of money on credit cards for calling, browsing and sending } \\
\text { messages on their cell phones. }\end{array}$ & 117 & 23 \\
\hline 2. & Some can even spend their feeding money on credit cards. & 116 & 24 \\
\hline 3. & Some go to the extent of stealing in order to buy credit cards to call. & 96 & 44 \\
\hline 4. & An undergraduate could be moody for a whole day if there is no money to buy credit cards. & 89 & 51 \\
\hline & Total & 499 & 201 \\
\hline
\end{tabular}

\begin{tabular}{|c|c|c|c|}
\hline & Average Observed Responses & Df & X2c \\
\hline Agree & $99.8(70)^{*}$ & \multirow{2}{*}{25.372} \\
\hline Disagree & $40.2(70)^{*}$ & & \\
\hline
\end{tabular}

$\mathrm{X}^{2} \mathrm{t}=3.841 \mathrm{P}<0.05$ (significant) $^{\star}$ Expected cell frequency 
Table 4 shows that the calculated chi square value which is 25.372 is greater that table value which is 3.841 . Hence the result is significant. This implies that students' perception of cell phone and financial addiction implication were related

\section{Discussion}

The result on Table 1 shows that there is no significant relationship between students' perception of cell phone and emotional reactions such as fear, sadness, joy, anger, surprise and feelings of guilt due to inability to return all calls and messages. This result negates the view of Sanchez et al (2009). To them, exposure to mobile phones includes mental overload which has emotional implications. The use of mobile phone may trigger some negative and positive emotions for users.

The result in Table 2 indicates that there is no significant relationship between students' perception of cell phone and sleep disorder. This finding supports the view of Takao et al (2009) who say that the perception of individuals on the use of cell phones depends on how individuals perceive the possibility of be disturbed at odd hours, even at midnight. While some may feel disturbed, others may welcome the idea of receiving calls at night.

The result in Table 3 indicates that there is significant relationship between students' perception of cell phone and the types of message received. This result supports the claim of Sanchez and Otero (2009) that people can have feelings of guilt due to inability to return all calls and messages. This inability to return all calls may be due to emotional aspects of the message. If the message is not good enough, someone may not be pleased to reply such a message. While a good message may receive prompt reply and attention.

The result in Table 4 indicates that there is significant relationship between students' perception of cell phone and financial addiction implication. The result supports the view of Takao et al (2009) who say that young people are sometimes addicted to mobile phones by over using them and this prompts them to spend a lot on the purchase of credit cards in order to call, browse and do other related things on the phone. They could be tempted, at times to spend money meant for other valuable things on credit cards.

\section{Recommendation}

Based on the findings of this study, it is recommended that individual users of cell phones should have time of turning off their phones in order to be focused, rest enough and to improve their well-being. This is all about attitude and habit. The moment someone is used to putting off the cell phone for a particular reason to improve his or her being, the callers will get used to it, and they will be aware of more convenient time to call. And if text messages were sent while the phone was switched off, the messages would be received instantly.

The users of cell phones should not be expecting others to be available at all times, so, when calls are made, and one is not able to get in touch, one should not be disturbed, perceive the situation wrongly or attach emotions to it.

Cell phone users should not be desperate on the use of phones by spending a lot of money to purchase credit cards at the expense of other issues like feeding, payment of school fees and so on. The cell phone is good for brief information alertness and the likes. Spending a lot on calls that can be postponed may not be advisable for undergraduates who are still dependents.

Individuals who use cell phones should have some control over their phones. They should not be addicted to cell phones to the extent of harming themselves or others. Cell phones are made for man and not vice versa. Users should, therefore, exercise some level of self-control. Cell phones should not be allowed to interfere with our comfort, sleep, study, personal consecration and our preparation and sitting for public examinations.

\section{Conclusion}

That the advent of cell phone has impacted positively on the lives of adolescents cannot be easily over-emphasized. Because of the numerous functions that the cell phone performs, many adolescents now find it difficult to live without it. No doubt, the cell phone is one of the wonders of the $21^{\text {st }}$ Century.

The study has revealed that adolescents who are addicted to cell phones could spend money meant for other things on credit cards. Also, the type of messages received by adolescents on their cell phones is also significant. This implies that adolescents are emotional about the types of messages they receive on their phones. There is a great need to control and monitor the use of cell phones among the adolescents in order to reduce the social and psychological traumas that they undergo. 


\section{References}

Amkpa, S.A., and Okon, H.I. (2006). 'Assessment of students' GSM Phone Use Pattern at the Faculty of Education, University of Uyo.' An International Journal of Information and Communication and Technology (ICT). 3 (1). 37-42.

Aragbu-Akpore S. (2004). 'Nigeria is Telecom Investment Destination says ITU. 'Guardian Newspaper. Tuesday 11 May p. 41.

Craig, A.D. (2002). "How do you Feel? Interception: the Sense of the Physiological Condition of the Body. Nature Reviews Neuroscience. August: 38(8), 655-66.

Damasio, Antonio. (2007).'Neuroscience and Ethics: Intersection'. American Journal of Bioethics, 7: 1-3.

Gilroy, M.(2003). Invasion of the Classroom Cell Phones. The Hispanic Outlook in Higher Education, 14(6), 38-39.

Hunter -Carsch, M., Tiknare, Y., Cooper, Paul and Sage, R. (2006). Social, Emotional and Behavioural Difficulties. New York: Continuum International Publishing.

Johnson, C. \& Kristonis,W.A. (2007) National School Debate: Banning Cell Phones on Public School Campuses in America. National Forum of Educational Administration and Supervision Journal, 25(40. 1-6.

Kanfer, F.H., \& Goldstein, A.P. (1991). Helping people change (4th ed.). New York: Pergamon.

Levinson, Paul (2004). Cellphone: The Story of the World's Most Mobile Medium, and How it Has Transformed Everything. New York: Palgrave Macmillan.

Mutula, S.M, Komanyane, K and Grand, B (2005). "Cell Phone Use by Students at the University of Botswana: A Comparative Study of Library and Information Studies and other Departments." African Journal of Archives and Information Science. 15( 1), 81-85.

O'Leary, K.D., \& Wilson, G.T. (1987). Behaviour Therapy: Application and Outcome (2nd Ed.) Englewood Cliffs, NJ: Prentice-Hall.

Prensky, M. (2005). What can you learn from a Cell Phone? Almost Anything Innovate, 1(5)1-9,

Sanchez -Martinez, M., and Otero, A. (2009). 'Factors Associated with Cell Phone Use in Adolescents in the Community Madrid (Spain)'. Cyber Psychology and Behaviour .12(12): 131-137.

Takao, M., Takahashis, S. and Kitamura, M. (2009). 'Addiction Personality and Problematic Mobile Phone Use.' Cyber Psychology and Behaviour. 12(5), 501506.

Weisz, J.R., Hawley, K.M., \& Doss, A.J (2004). Empirically Tested Psychotherapies for Youth Internalizing and Externalizing Problem and Disorders. Child \& Adolescents Psychiatric Clinics of North America 13,729-815. 
ISSN 2239-978X

ISSN 2240-0524
Journal of Educational and Social Research MCSER Publishing, Rome-Italy
Vol. 4 No. 6 September 2014 